\title{
Potential Anti-metastasis Natural Compounds for Lung Cancer
}

\author{
PITHI CHANVORACHOTE ${ }^{1}$, SUPAKARN CHAMNI ${ }^{2}$, \\ CHUANPIT NINSONTIA ${ }^{1}$ and PREEYAPORN PLAIMEE PHIBOONCHAIYANAN ${ }^{1}$
}

${ }^{1}$ Cell-Based Drug and Health Product Development Research Unit and Department of Pharmacology and Physiology, Faculty of Pharmaceutical Sciences, Chulalongkorn University, Bangkok, Thailand; ${ }^{2}$ Center for Bioactive Natural Products from Marine Organisms and Endophytic Fungi (BNPME), Department of Pharmacognosy and Pharmaceutical Botany, Faculty of Pharmaceutical Sciences, Chulalongkorn University, Bangkok, Thailand

\begin{abstract}
As lung cancer is the most common malignancy worldwide and high mortalities are the result of metastasis, novel information surpassing the treatment strategies and therapeutic agents focusing on cancer dissemination are of interest. Lung cancer metastasis involves increased motility, survival in circulation and ability to form new tumors. Metastatic cells increase their aggressive features by utilizing several mechanisms to overcome hindrances of metastasis, including epithelial to mesenchymal transition (EMT), increased in cellular survival and migratory signals. Sufficient amounts of natural product-derived compounds have been shown to have promising anti-metastasis activities by suppressing key molecular features upholding such cell aggressiveness. The knowledge regarding molecular mechanisms rendering cell dissemination together with the anti-metastasis information of natural product-derived compounds may lead to development of novel therapeutic strategies.
\end{abstract}

Lung cancer causes mortality in the estimated number of 1.5 million every year $(1,2)$. It has been widely accepted that in most aggressive malignancies, metastasis becomes the highlighted topic of research interests. In lung cancer, the metastasis-related death is found to be as high as $90 \%$ of all lung cancer mortality and approximately $70 \%$ of lung cancer patients are found with local lymph node metastasis or

This article is freely accessible online.

Correspondence to: Pithi Chanvorachote, Ph.D., Department of Pharmacology and Physiology, Faculty of Pharmaceutical Sciences, Chulakongkorn University, Phatumwan, Bangkok, 10330 Thailand. Tel: +66 812075039, Fax: +66 22188340, e-mail: pithi_chan@yahoo.com

Key Words: Lung cancer, metastasis, anti-metastasis, natural product, anti-cancer, review. distant spreading of cancer at the time of first diagnosis (3). According to such contexts, metastasis is an important impediment for the successful therapy of lung cancer and, thus, understanding of the underlying molecular basis in regulation of lung cancer dissemination may lead to discovery of novel effective targeted therapies.

Lung cancer is generated from normal lung epithelial cells that undergo multiple genetic damages and finally transform to uncontrolled proliferating cells with abnormal growth and aggressive behaviors in the airway of lungs. Lung cancer consists of two major types: non-small cell lung cancer ((NSCLC); 85\% of all lung cancer cases) and small-cell lung cancer ((SCLC); about 15\%) $(4,5)$. According to the histological classification, NSCLC can be divided into three major subtypes: squamous cell carcinoma, adenocarcinoma and large-cell carcinoma (4). The importance of classification is revealed to treatment strategy and prediction of cancer outcome. At the present day, surgery, radiation, chemotherapy and targeted therapy are used in lung cancer treatment; however, despite the fact that multiple approaches have been used for lung cancer treatment, the clinical outcomes of the current therapies are still not at satisfactory level.

Many widely prescribed chemotherapeutic agents have been discovered by investigating the potential compounds from plants, marine organisms, microorganisms and animals or developing from the natural product-derived lead compounds (6). In line with such a concept, several natural product-derived compounds have been currently evaluated and their anti-cancer activities have been focused on newly discovered mechanisms with the hope that they can be used or, at least, lead to better strategies against cancer (Table I).

\section{Mechanism of Metastasis}

Until now, the mechanism of metastasis of lung cancer is still not understood at a sufficient level. Although the appearance 
and phenotype of the metastatic cancer cells found in other parts of the body is similar to that of primary tumor cells, metastatic lung cancer cells have several different molecular features. With the same feature of certain proteins and chromosome defects found in original lung cancer cells, the metastatic cells possess specific signals that enhance their ability to metastasize. Such mechanisms allow the cells to disseminate from their original site. In general, lung cancer cell metastasis involves the common following steps as found in most solid tumors, which are (i) detachment from extracellular matrix (ECM), (ii) local migration and invasion, (iii) intravasation into blood or lymphatic systems, (iv) survival in circulatory system (resistant to anoikis), (v) extravasation at metastatic site and (vi) proliferation and formation of new tumor. The illustration of complicated processes of metastasis is shownin Figure 1.

The metastatic cells require special properties to overcome hindrances, with the most important being their ability to survive in detached conditions, invade and generate new tumors. Recent studies have shown that adaptive cell features changing from epithelial-like to mesenchymal phenotypes named "epithelial to mesenchymal transition" (EMT) (7-9) and cancer stem cells (CSCs) $(8,10-13)$ play critical roles in facilitating cancer cell dissemination. In addition, the augmentation of survival mechanisms, including Protein kinase B (AKT), ERK and anti-apoptotic protein members of the Bcl-2 family, have been intensively shown to increase metastasis ability of lung cancer cells (14-18).

\section{Anoikis Regulatory Mechanism}

Anoikis is the molecular event of programed cell death triggered by the loss of appropriate cell contact to extracellular matrix or basement membrane. The process of anoikis involves the lack or diminishment of integrin-mediated survival signals (19). This death is found in most adherent cells, including solid tumor cells (20); therefore, anoikis has been recognized as a key impediment of cancer metastasis. Molecules like focal adhesion kinase (FAK), anti-apoptotic protein MCL-1 and caveolin-1 (CAV-1) have been shown to inhibit anoikis in lung cancer cells. Regarding FAK, it is a focal adhesion-associated protein, encoded by PTK2 gene (protein tyrosine kinase). FAK acts as an essential early protein that co-localizes with integrins on the cytoplasmic domain and facilitates migration through transmission of integrin signaling. FAK is recruited and activated by signaling from integrin. The major phosphorylation site of FAK is identified as tyrosine 397 (Tyr 397). After FAK auto-phosphorylation, activated FAK forms a complex with SRC family kinases, which generate multiple downstream signaling through phosphorylation of other proteins to regulate cell survival (21). In lung cancer cells, FAK was shown to enhance cell survival in detached conditions via PI3K/AKT and MAPK-ERK pathways (22).
Recently, CAV-1 protein, a main component of caveolae, has been demonstrated to negatively control anoikis response in NSCLC cells $(23,24)$. In mechanistic detail, CAV-1 was shown to inhibit anoikis in lung cancer cells by its binding on and stabilizing of anti-apoptotic MCL-1 protein (25). The direct interaction of CAV-1 protects MCL-1 from ubiquitinproteasomal degradation (25). Other possible mechanism of CAV-1 on anoikis resistance is that the protein can upregulate the insulin-like growth factor-I receptors and enhance its downstream AKT signaling (26). Together with the facts that CAV-1 was shown to be highly expressed in metastatic and advanced stage cancer (27-29) and its expression was linked with poor prognosis $(30,31)$, suppressing this protein may be a potential way to overcome anoikis resistance and, as a consequence, inhibit metastasis.

Mounting evidence has demonstrated the activity of natural products in attenuation of cancer metastasis. Among several potential nature-derived compounds, curcumin [1], a compound isolated from the rhizome of turmeric (Curcuma longa), has garnered considerable attention over the past decade. Curcumin has been shown to sensitize anoikis in lung cancer cells by mediating Bcl-2 down-regulation (32). The study provided evidence that treatment of lung cancer cells with non-toxic concentrations of curcumin enhanced the degradation of $\mathrm{Bcl}-2$ protein via ubiquitin-proteasomal degradation that, finally, resulted in the sensitization of anoikis (32).

The compound derived from Angelica dahurica root, imperatorin [2], was shown to increase anoikis response of lung cancer cells and inhibit anchorage-independent growth of lung cancer cells by down-regulation of MCL-1 protein (33). Likewise, artonin E [3], a compound obtained from Artocarpus gomezianus, and ecteinascidin 770 [ET-770, 4] isolated from marine tunicate Ecteinascidia thurstoni, were demonstrated to have anoikis sensitizing activity by decreasing the MCL-1 protein their non-toxic concentrations in NSCLC cells $(34,35)$. Recently, renieramycin M [RM, 5], a bistetrahydroisoquinolinequinone separated from marine blue sponge Xestospongia sp., was reported as a potential anti-metastatic agent by sensitizing anoikis-resistant lung cancer cells to anoikis by suppressing survival proteins $\mathrm{p}$ ERK and p-AKT, along with anti-apoptotic proteins Bcl-2 and MCL-1 (36). Interestingly, ET-770 [4] and RM [5] consisted of similar chemical skeleton. The corresponding cytotoxicity and anti-cancer mechanism toward lung cancer potentially derived from the bistetrahydroisoquinoline core. A natural flavone isolated from the root of Scutellaria baicalensis known as Oroxylin A [6] was found to sensitize A549 cells to anoikis by inactivating the c-Src/AKT/HK II pathway (37). Furthermore, a mixture of flavonoids extracted from Korean Citrus aurantium was also reported to induce apoptosis of NSCLC (A549) cells involving protein cleaved caspase-3 and p-p53 (38). 


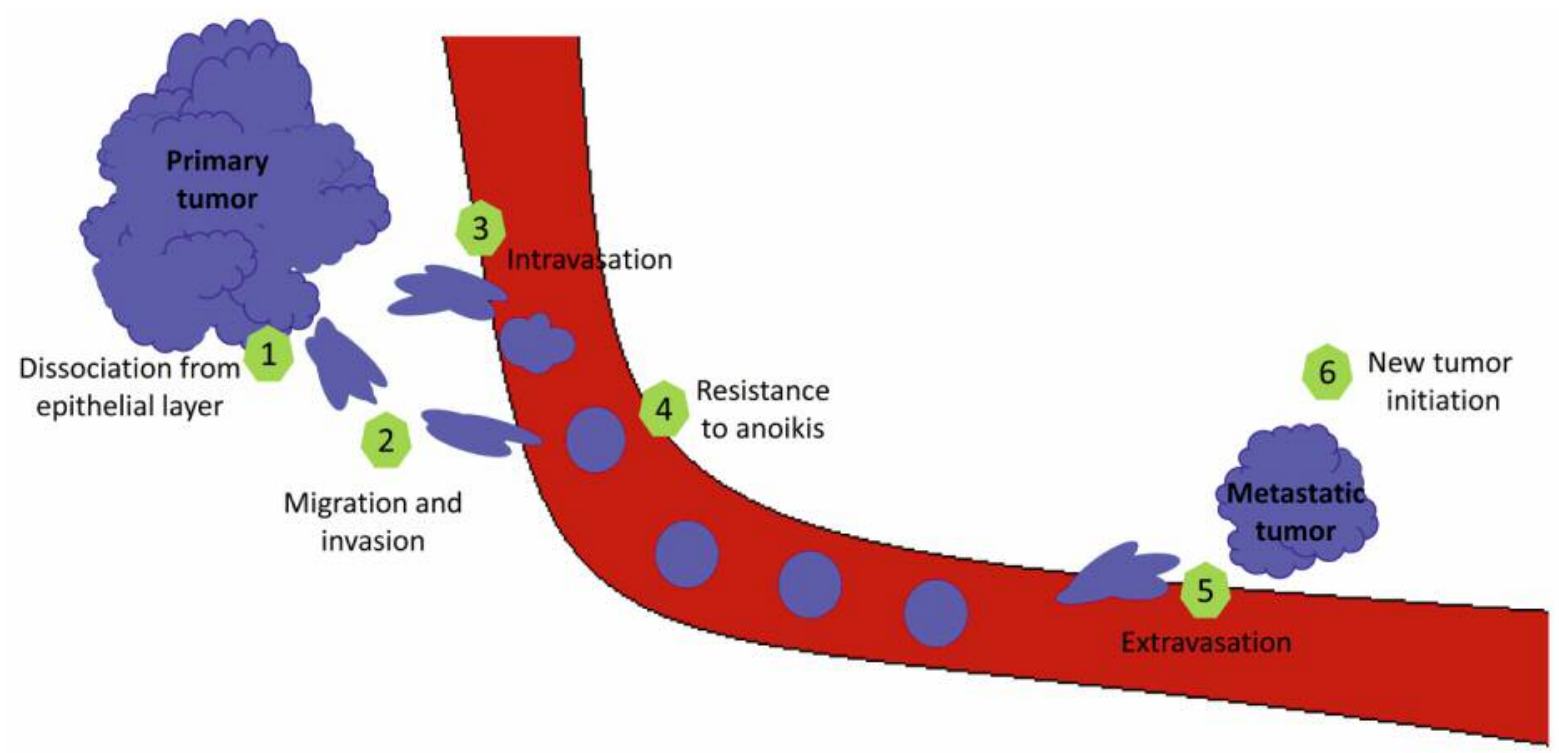

Figure 1. Cancer metastatic process. Metastasis is a complicated multistep process beginning with cancer cell detachment from extracellular matrix $(E C M)$, migration, invasion and extravasation to the circulation. When the cancer cells reach secondary sites, they adhere, intravasate and begin dividing to form new tumors.

\section{EMT and Migratory Suppression}

EMT is a process of epithelial cells undergoing phenotypic change to mesenchymal cells. In general, EMT occurs during embryonic development, wound repair and pathological events, such as fibrosis and cancer (39).

EMT is classified into three different subtypes: 1) Type 1 EMT: This type occurs during embryonic development and organogenesis; 2) Type 2 EMT: This type associates with tissue repair and fibrosis; 3) Type 3 EMT: This type associates with cancer progression and metastasis.

EMT characteristics can be identified by the change of cell morphology and expression of EMT markers. During EMT, epithelial cells undergo remarkable morphological conversion from cobblestone-like epithelial morphology to elongated-like mesenchymal morphology. The crucial hallmark of EMT is the loss of E-cadherin, a cellular junction protein typically expressed in epithelial cells. In addition, EMT-phenotypic cells increase the expression of mesenchymal markers, such as $\mathrm{N}$-cadherin and vimentin, as well as up-regulate transcriptional factors, namely Snail and Slug (39-42). The alteration of cell components, including adhesion molecules and cytoskeleton, makes the cells lose their polarity and acquired high migratory ability, thus facilitating cancer cell metastasis.

Focusing on cancer metastasis, accumulating evidences have indicated the roles of EMT in cancer aggressiveness and metastasis; EMT is being considered as the underlying cause of the high mortality rate of cancer (7-9). EMT elicits distinct behaviors leading to cancer cell metastasis, including increased cell motility (migration and invasion) and anoikis resistance. Previous studies have demonstrated that loss of E-cadherin expression has been shown to decrease cell polarity and promote individual cell migration and invasion (43-46). Accordingly, the increased expression of N-cadherin results in a less stable cell-cell adhesion, which promotes cell motility and invasion by maintaining the steady-state level of active Rac1 $(45,46)$. Similar to N-cadherin, vimentin, type III intermediate filament protein, plays a predominant role in the changes in cell shape, adhesion and motility by maintaining FAK activity and Rac1 activation $(47,48)$.

During EMT process, lung cancer cells enhance their expression of mesenchymal transcription factors, such as, Slug, Snail and Twist. Besides, the increase of proteins like vimentin, fibronectin and alpha-smooth muscle actin $(\alpha-$ SMA), as well as the reduction of E-cadherin, have been shown to induce cell morphology change toward spindle shape and detachment of the cells form their basement. Focusing on cancer invasion, the augmented $\mathrm{N}$-cadherin found in EMT cells encourages invasive and metastasis behaviors (49). EMT was also shown to increase cell invasive ability by triggering matrix metalloproteinases (MMPs), such as MMP-2, MMP-3 and MMP-9 (50). In NSCLC, the low vimentin level was found to be a predictor of better survival in primary NSCLC (51). EMT phenotypes in primary cells of lung cancer have been shown to link with anoikis and chemotherapeutic resistance $(52,53)$. Focusing on cancer cells and their environment interplays, EMT can be induced by several 
Table I. Natural product-derived compounds as potential anti-lung cancer agents.

\begin{tabular}{|c|c|c|c|c|}
\hline Entry & Compound & Natural source & $\begin{array}{l}\text { Origin/ } \\
\text { Part use }\end{array}$ & $\begin{array}{l}\text { Anti-lung cancer } \\
\text { mechanism }\end{array}$ \\
\hline 1 & Curcumin, 1 & Curcuma longa & $\begin{array}{l}\text { Plant/ } \\
\text { Rhizome }\end{array}$ & $\begin{array}{l}\text { Anoikis } \\
\text { sensitizing }\end{array}$ \\
\hline 2 & & $\begin{array}{l}\text { Angelica } \\
\text { dahurica }\end{array}$ & $\begin{array}{l}\text { Plant/ } \\
\text { Root }\end{array}$ & $\begin{array}{l}\text { Anoikis } \\
\text { sensitizing }\end{array}$ \\
\hline 3 & & $\begin{array}{l}\text { Artocarpus } \\
\text { gomezianus }\end{array}$ & $\begin{array}{l}\text { Plant/ } \\
\text { Bark }\end{array}$ & $\begin{array}{l}\text { Anoikis } \\
\text { sensitizing }\end{array}$ \\
\hline 4 & teinascidin 770,4 & $\begin{array}{l}\text { Ecteinascidia } \\
\text { thurstoni }\end{array}$ & $\begin{array}{l}\text { Tunicate/ } \\
\text { Whole } \\
\text { body }\end{array}$ & $\begin{array}{l}\text { Anoikis } \\
\text { sensitizing }\end{array}$ \\
\hline 5 & $\begin{array}{c}\mathrm{Me} \\
\text { Renieramycin M, }\end{array}$ & $\begin{array}{l}\text { Xestospongia } \\
\text { sp. }\end{array}$ & $\begin{array}{l}\text { Sponge/ } \\
\text { Whole } \\
\text { body }\end{array}$ & $\begin{array}{l}\text { Anoikis } \\
\text { sensitizing }\end{array}$ \\
\hline 6 & Oroxylin $A, 6$ & $\begin{array}{l}\text { Scutellaria } \\
\text { baicalensis }\end{array}$ & Plant/root & $\begin{array}{l}\text { Anoikis } \\
\text { sensitizing }\end{array}$ \\
\hline
\end{tabular}


Table I. Continued

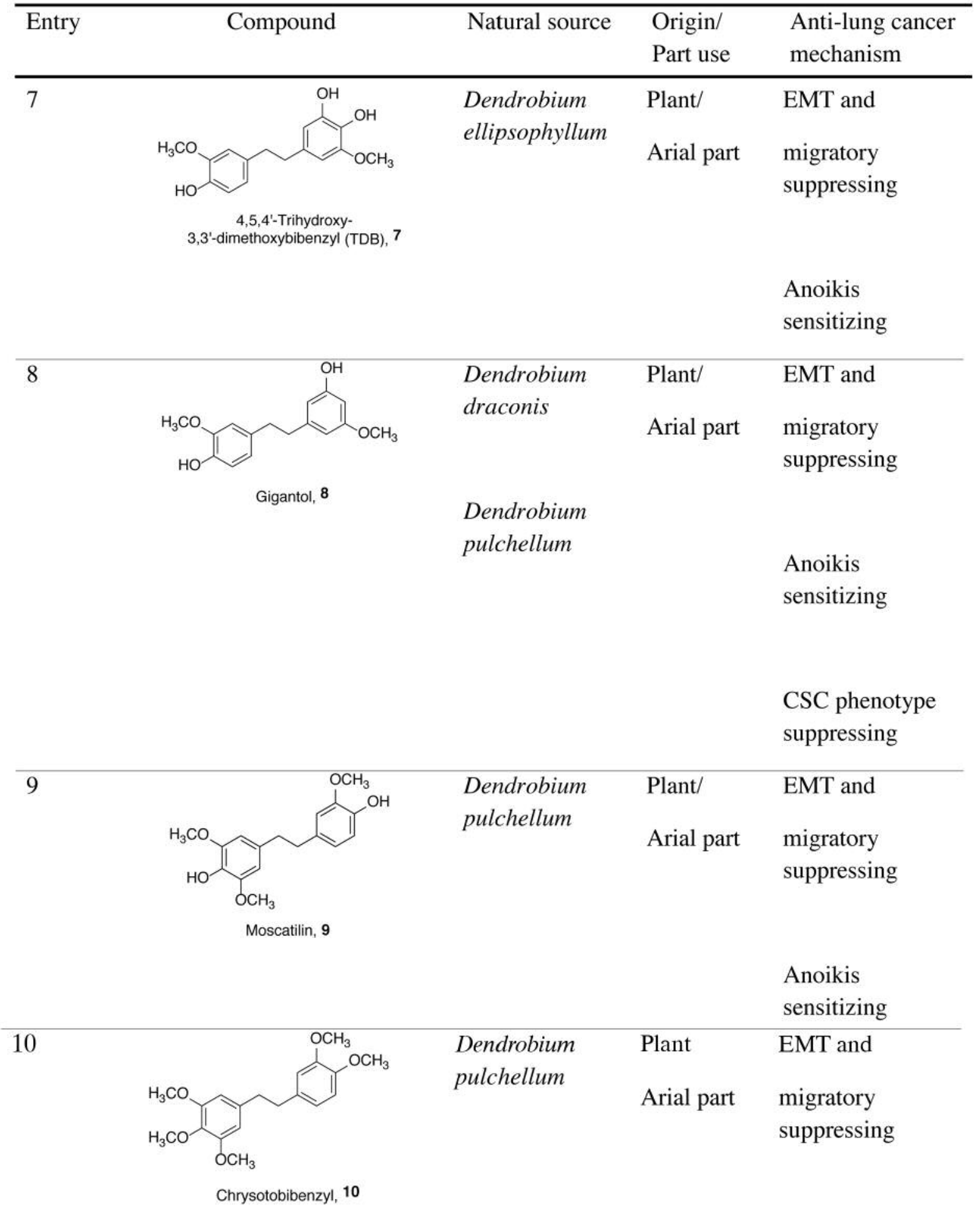

Anoikis sensitizing 
Table I. Continued

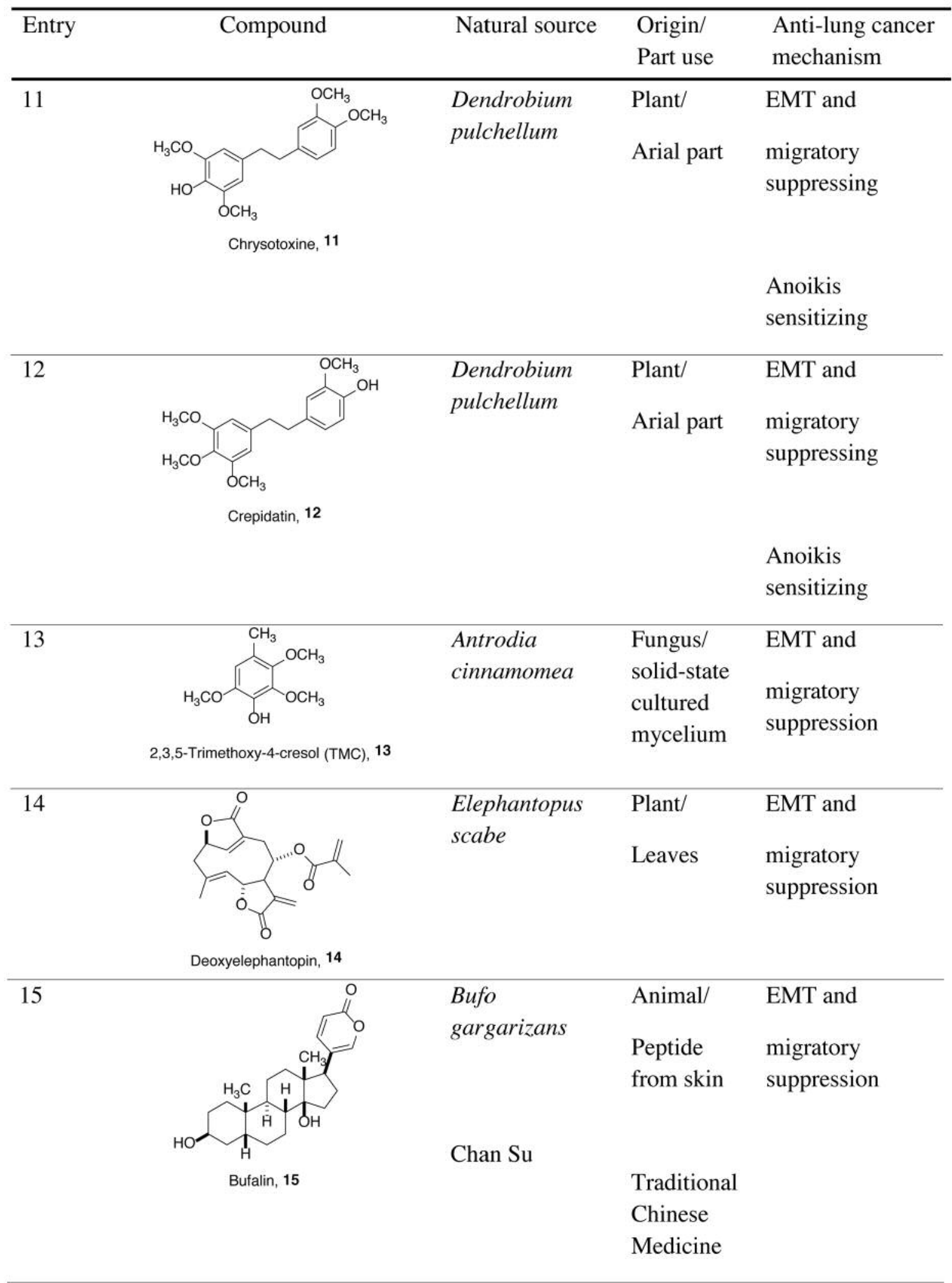


Table I. Continued

\begin{tabular}{|c|c|c|c|c|}
\hline Entry & Compound & Natural source & $\begin{array}{l}\text { Origin/ } \\
\text { Part use }\end{array}$ & $\begin{array}{l}\text { Anti-lung cancer } \\
\text { mechanism }\end{array}$ \\
\hline 16 & icatechin-3-gallate & $\begin{array}{l}\text { Camellia } \\
\text { sinensis }\end{array}$ & Plant/ leave & $\begin{array}{l}\text { EMT and } \\
\text { migratory } \\
\text { suppression }\end{array}$ \\
\hline 17 & & $\begin{array}{l}\text { Scutellaria } \\
\text { baicalensis }\end{array}$ & Plant/Root & $\begin{array}{l}\text { EMT and } \\
\text { migratory } \\
\text { suppression }\end{array}$ \\
\hline 18 & $\begin{array}{l}\mathrm{OH} \mathrm{O} \\
\text { Wogonin, } 18\end{array}$ & $\begin{array}{l}\text { Scutellaria } \\
\text { baicalensis }\end{array}$ & Plant/Root & $\begin{array}{l}\text { EMT and } \\
\text { migratory } \\
\text { suppression }\end{array}$ \\
\hline
\end{tabular}

extracellular signals, including transforming growth factor- $\beta 1$ (TGF- $\beta 1$ ), interleukin-6 (IL-6) and nitric oxide, cancerassociated immune cells and fibroblasts (54-56).

As EMT phenotypes have been strongly linked to anoikis resistance and other aggressive behaviors of cancer cells, compounds that can suppress EMT is of interest for the development of anti-metastasis approaches. Several natural products have been shown to have abilities to suppress EMT in lung cancer cells. A bibenzyl 4,5,4'-trihydroxy-3,3'dimethoxybibenzyl [TDB, 7], isolated from Dendrobium ellipsophyllum, has been demonstrated to inhibit EMT and sensitize lung cancer cells to anoikis (57). Treatment of lung cancer cells with non-toxic concentrations of TDB significantly suppressed EMT markers, namely vimentin and Snail, while increased the level of E-cadherin. Also, such a decrease in EMT phenotypes was shown to induce anoikis and decrease cell growth in detached conditions by reduction of activated protein kinase B (p-AKT) and activated extracellular signalregulated kinase (p-ERK) (57). Gigantol [8], extracted from Dendrobium draconis, and known bibenzyl compounds, including moscatilin [9], chrysotobibenzyl [10], chrysotoxine [11] and crepidatin [12], isolated from Dendrobium pulchellum, have been demonstrated to suppress EMT in a lung cancer cell model and such suppression resulted in the induction of anoikis and decreased growth in an anchorage-independent manner $(58,59)$. The EMT inhibition of moscatilin [9] was recently described via mesenchymal cell markers' suppression, including vimentin, Slug and Snail (60). In addition, 2,3,5trimethoxy-4-cresol [TMC, 13], a substituted phenol obtained from Taiwanese edible fungus Antrodia cinnamomea, was reported as an effectively lung cancer migratory suppressing agent by reducing protein expression of AKT, MMP-2 and MMP-9 in conjugation with enhancing E-cadherin and TIMP1 protein expression in A549 cancer cell line at subtoxic concentrations (61). Similar results were observed from the anti-metastatic study in A549 cells of deoxyelephantopin [14], a sesquiterpenelactone from Elephantopus scabe. This complex natural lactone suppressed the activation of p-ERK1/2 and pAKT and exhibited down-regulation of NF-kB, IkB $\alpha$ MMP-2, MMP-9, uPA and uPAR. In addition, deoxyelephantopin [14] was associated with the up-regulation of TIMP2 without changing the TIMP1 protein level (62). Moreover, bufalin [15], a cardiotonic steroid originally isolated from serous fluid of Chinese toad, found as a component in Chan Su (a traditional 
Chinese medicine), was recently investigated for its antimetastasis effects on NCI-H460 lung cancer cells where suppression of MMP-2, MMP-9, MAPKs and NF-kB was observed (63). Several natural flavonoids have been investigated as potential anti-metastasis agents toward various lung cancer cell lines. Epicatechin-3-gallate [16], a natural flavonoid found in green tea, was reported to reverse the TGF$\beta 1$-induced EMT and up-regulated epithelial markers, such as E-cadherin (64). Moreover, flavone components in Scutellaria baicalensis, including baicalein [17] and wogonin [18], induced down-regulation of MMP-2 and MMP-9 in both A549 and H1299 cells (65).

\section{Cancer Stem Cells (CSCs)}

Accumulative evidence have pointed out the importance of small sub-populations within tumors with stem cell properties named "Cancer Stem Cells (CSCs)" on the process of carcinogenesis, cancer progression and metastasis (66). In lung cancer, the specific side-population has been isolated from lung cancer cell lines with CSC properties $(67,68)$.

The properties of CSCs are similar to those of normal stem cells within tissues. CSCs have the ability to self-renewal and can produce differentiated progeny through their pluripotency (69). It has been demonstrated that these CSCs in lung cancer resist to chemotherapeutic agents and have high tumorigenic potential $(12,70)$. Also, the lung CSCs were shown to have augmented ability to move to other tissues $(8,12,71)$. The most important characteristic of CSCs is their ability to generate a new tumor. As a result of their self-renewal and differentiation capabilities, CSCs are believed to initiate tumor, as well as generate new tumors, at distant parts of the body. Nowadays, this new paradigm of CSCs has become the most interesting topic in research, clinical assessments and drug discovery and development, in particular, in lung cancer.

Due to their stem cell-like properties of tumorigenic potential and pluripotency, CSCs are believed to be key players of cancer metastasis and relapse $(8,10-13)$. Several CSC makers have been used to identify the CSC population in lung cancer, including cellular expression of CD44, CD133 and CD166 (67-71). Also aldehyde dehydrogenase (ALDH) activity and expression have been shown to indicate stemness in lung cancer (67-71). In NSCLC, the CD44possitive cells have been shown to have enhanced stem celllike properties (72).

Currently, CSCs, as well as their behaviors, were shown to be regulated through the interaction with their microenvironment. In detail, the activity of self-renewal and differentiation can be modulated in response to the signals form environment (72). Focusing on lung cancer, evidence has shown that hypoxic conditions increased the population of CSCs through the activation of insulin-like growth factor 1 (IGF1) receptor (73). Also, the important biological mediator nitric oxide was found to enhance stem cell-like phenotypes in NSCLC cells (56). The study by Yongsanguanchai et al. revealed that exposure of lung cancer cells with a long-term low dose of nitric oxide gradually increased the CSC makers and phenotypes in a time-and dose-dependent manner. Interestingly, this study demonstrated that induction of CSCs by nitric oxide is reversible. By withdrawal of nitric oxide after long-term treatment, the increase in CSCs was found to reverse to the baseline level comparable with the non-treated cells (56), thus suggesting the dynamic response of the CSCs to their environment.

In terms of molecular views, the molecular pathway found in normal stem cells, such as Wnt $(74,75)$, Notch $(76,77)$, Hedgehog (78) and PI3K/AKT, have been shown to regulate stem cell properties in lung cancer. The role of Wnt signal has been intensively elucidated in lung CSC regulation. Wnt was shown to control the expression of stem cell transcription factor Oct4 in lung CSCs (74). Also, the regulatory effect of $\mathrm{Wnt}$ has been demonstrated in several lung cancer cells, while the blockage of Wnt signal in lung CSCs was shown to inhibit growth and exhibit anti-cancer activity (79-81). For Notch signaling, its function was positively linked with the proliferation of CD133-possitive lung CSCs (76). The inhibition of Notch in CD133-possitive lung cancer cells resulted in growth halt and sensitive response to chemotherapy (76). Accordingly, cisplatin treatment of lung cancer cells resulted in enriched CD133possitive population through Notch signaling (82). The central cell survival signal AKT has been indicated as a principle regulator for stemness in lung CSCs. Studies in several NSCLC cell lines and primary human tumors grown in nude mice have shown that AKT is an essential upstream activator of Sox-2 in regulation of lung cancer stem-like phenotypes (83). Besides, the microRNA-31 was shown to inhibit lung CSCs through the suppression of PI3K/AKT (84). These evidences suggested the potential molecular targets for targeted therapy focusing on lung CSC.

In NSCLC, the plant-derived compound isolated form Dendrobium draconis, gigantol [8] was shown to reduce cancer stem cell-like phenotypes through AKT suppression (85). Gigantol at its non-toxic concentrations was shown to suppress CSC phenotypes and CSC makers CD133 and ALDH1A1 in lung cancer cells. Moreover, the suppressed CSC phenotypes were found as a consequence of AKT inhibition, which, in turn, decreased the cellular levels of pluripotency and self-renewal factors Oct4 and Nanog (85).

\section{Conclusion}

The current molecular technologies, as well as the discovery of new paradigms in cancer cell biology, have emphasized the potential of targeted therapy for treatment of cancers. Although several questions remain unanswered, including the key 
pathways in controlling EMT and CSCs and the effect of environmental factors, the defined regulatory pathways underlying lung cancer metastasis form the critical basis for the development of novel strategies in overcoming lung cancer.

Nature has been long recognized as a very important and attractive source of new therapeutic compounds due to the chemical diversity found in plants, animals, marine organisms and microorganisms allowing us to select the compounds for our specific targets. This review concludes the currently focused molecular mechanisms in the area of lung cancer metastasis and provides information of potential natural derived compounds for anti-metastatic approaches. The provided information may support further investigations and development for using such compounds in cancer therapy.

\section{Acknowledgements}

This research is supported by the Thailand Research Fund (RSA780043).

\section{References}

1 Jemal A, Bray F, Center MM, Ferlay J, Ward E and Forman D: Global cancer statistics. CA Cancer J Clin 61: 69-90, 2011.

2 Youlden DR, Cramb SM and Baade PD: The International Epidemiology of Lung Cancer: Geographical distribution and secular trends. J Thorac Oncol 3: 819-831, 2008.

3 Hirsch FR and Hansen HH: New techniques for early diagnosis of lung cancer. Ugeskr Laeger 163: 4321-4323, 2001.

4 Goldstraw P, Ball D, Jett JR, Le Chevalier T, Lim E, Nicholson AG and Shepherd FA: Non-small-cell lung cancer. The Lancet 378: 1727-1740, 2011.

5 van Meerbeeck JP, Fennell DA and De Ruysscher DK: Smallcell lung cancer. Lancet 378: 1741-1755, 2011.

6 Kinghorn A. Drug discovery from natural products. In: Foye WO, Lemke TL, Williams DA, editors. Foye's Principles of Medicinal Chemistry: Lippincott Williams \& Wilkins; 2008. p. 12-25.

7 da Silva SD, Morand GB, Alobaid FA, Hier MP, Mlynarek AM, Alaoui-Jamali MA and Kowalski LP: Epithelial-mesenchymal transition (EMT) markers have prognostic impact in multiple primary oral squamous cell carcinoma. Clin Exp Metastasis 32: 55-63, 2015.

8 Mehlen P and Puisieux A: Metastasis: A question of life or death. Nat Rev Cancer 6: 449-458, 2006.

9 Tanaka Y, Terai Y, Kawaguchi H, Fujiwara S, Yoo S, Tsunetoh S, Takai M, Kanemura M, Tanabe A and Ohmichi M: Prognostic impact of EMT (epithelial-mesenchymal-transition)-related protein expression in endometrial cancer. Cancer Biol Ther 14: 13-19, 2013

10 Hermann PC, Huber SL, Herrler T, Aicher A, Ellwart JW, Guba M, Bruns CJ and Heeschen C: Distinct populations of cancer stem cells determine tumor growth and metastatic activity in human pancreatic cancer. Cell Stem Cell 1: 313-323, 2007.

11 Merlos-Suarez A, Barriga FM, Jung P, Iglesias M, Cespedes MV, Rossell D, Sevillano M, Hernando-Momblona X, da Silva-Diz V, Munoz P, Clevers H, Sancho E, Mangues R and Batlle E: The intestinal stem cell signature identifies colorectal cancer stem cells and predicts disease relapse. Cell Stem Cell 8: 511-524, 2011.
12 Perona R, Lopez-Ayllon BD, de Castro Carpeno J and BeldaIniesta $\mathrm{C}$ : A role for cancer stem cells in drug resistance and metastasis in non-small-cell lung cancer. Clin Transl Oncol 13: 289-293, 2011.

13 Scheel C and Weinberg RA: Cancer stem cells and epithelialmesenchymal transition: concepts and molecular links. Semin Cancer Biol 22: 396-403, 2012.

14 Liu B, Wu X, Liu B, Wang C, Liu Y, Zhou Q and Xu K: MiR26a enhances metastasis potential of lung cancer cells via AKT pathway by targeting PTEN. Biochim Biophys Acta 1822: 16921704, 2012.

15 McCubrey JA, Steelman LS, Chappell WH, Abrams SL, Wong EW, Chang F, Lehmann B, Terrian DM, Milella M, Tafuri A, Stivala F, Libra M, Basecke J, Evangelisti C, Martelli AM and Franklin RA: Roles of the Raf/MEK/ERK pathway in cell growth, malignant transformation and drug resistance. Biochim Biophys Acta 1773: 1263-1284, 2007.

16 Roberts PJ and Der CJ: Targeting the Raf-MEK-ERK mitogenactivated protein kinase cascade for the treatment of cancer. Oncogene 26: 3291-3310, 2007.

17 Ikegaki N, Katsumata M, Minna J and Tsujimoto Y: Expression of bcl-2 in small cell lung carcinoma cells. Cancer Res 54: 6-8, 1994.

18 Anagnostou VK, Lowery FJ, Zolota V, Tzelepi V, Gopinath A, Liceaga C, Panagopoulos N, Frangia K, Tanoue L, Boffa D, Gettinger S, Detterbeck F, Homer RJ, Dougenis D, Rimm DL and Syrigos KN: High expression of BCL-2 predicts favorable outcome in non-small cell lung cancer patients with non squamous histology. BMC Cancer 10: 186, 2010.

19 Boudreau NJ and Jones PL: Extracellular matrix and integrin signalling: the shape of things to come. Biochem J 339(Pt 3): 481-488, 1999.

20 Frisch SM and Francis H: Disruption of epithelial cell-matrix interactions induces apoptosis. J Cell Biol 124: 619-626, 1994.

21 Beausejour M, Noel D, Thibodeau S, Bouchard V, Harnois C, Beaulieu JF, Demers MJ and Vachon PH: Integrin/Fak/Srcmediated regulation of cell survival and anoikis in human intestinal epithelial crypt cells: selective engagement and roles of PI3-K isoform complexes. Apoptosis 17: 566-578, 2012.

22 Liu G, Meng X, Jin Y, Bai J, Zhao Y, Cui X, Chen F and Fu S: Inhibitory role of focal adhesion kinase on anoikis in the lung cancer cell A549. Cell Biol Int 32: 663-670, 2008.

23 Chanvorachote P, Pongrakhananon V and Halim H: Caveolin-1 regulates metastatic behaviors of anoikis resistant lung cancer cells. Mol Cell Biochem 399: 291-302, 2015.

24 Halim H, Luanpitpong S and Chanvorachote P: Acquisition of anoikis resistance up-regulates caveolin-1 expression in human nonsmall cell lung cancer cells. Anticancer Res 32: 1649-1658, 2012.

25 Chunhacha P, Pongrakhananon V, Rojanasakul Y and Chanvorachote P: Caveolin-1 regulates Mcl-1 stability and anoikis in lung carcinoma cells. Am J Physiol Cell Physiol 302: C1284-1292, 2012.

26 Ravid D, Maor S, Werner H and Liscovitch M: Caveolin-1 inhibits cell detachment-induced $\mathrm{p} 53$ activation and anoikis by upregulation of insulin-like growth factor-I receptors and signaling. Oncogene 24: 1338-1347, 2005.

27 Ho CC, Huang PH, Huang HY, Chen YH, Yang PC and Hsu SM: Up-regulated caveolin-1 accentuates the metastasis capability of lung adenocarcinoma by inducing filopodia formation. Am J Pathol 161: 1647-1656, 2002. 
28 Sloan KA, Marquez HA, Li J, Cao Y, Hinds A, O'Hara CJ, Kathuria S, Ramirez MI, Williams MC and Kathuria $\mathrm{H}$ : Increased PEA3/E1AF and decreased Net/Elk-3, both ETS proteins, characterize human NSCLC progression and regulate caveolin-1 transcription in Calu-1 and NCI-H23 NSCLC cell lines. Carcinogenesis 30: 1433-1442, 2009.

29 Ho CC, Kuo SH, Huang PH, Huang HY, Yang CH and Yang PC: Caveolin-1 expression is significantly associated with drug resistance and poor prognosis in advanced non-small cell lung cancer patients treated with gemcitabine-based chemotherapy. Lung Cancer 59: 105-110, 2008.

30 Moon KC, Lee GK, Yoo SH, Jeon YK, Chung JH, Han J and Chung DH: Expression of caveolin-1 in pleomorphic carcinoma of the lung is correlated with a poor prognosis. Anticancer Res 25: 4631-4637, 2005.

31 Yoo SH, Park YS, Kim HR, Sung SW, Kim JH, Shim YS, Lee SD, Choi YL, Kim MK and Chung DH: Expression of caveolin1 is associated with poor prognosis of patients with squamous cell carcinoma of the lung. Lung Cancer 42: 195-202, 2003.

32 Pongrakhananon V, Nimmannit U, Luanpitpong S, Rojanasakul $\mathrm{Y}$ and Chanvorachote P: Curcumin sensitizes non-small cell lung cancer cell anoikis through reactive oxygen species-mediated Bcl-2 downregulation. Apoptosis 15: 574-585, 2010.

33 Choochuay K, Chunhacha P, Pongrakhananon V, Luechapudiporn $\mathrm{R}$ and Chanvorachote $\mathrm{P}$ : Imperatorin sensitizes anoikis and inhibits anchorage-independent growth of lung cancer cells. J Nat Med 67: 599-606, 2013.

34 Wongpankam E, Chunhacha P, Pongrakhananon V, Sritularak B and Chanvorachote P: Artonin E mediates MCL1 downregulation and sensitizes lung cancer cells to anoikis. Anticancer Res 32: 5343-5351, 2012.

35 Powan P, Saito N, Suwanborirux K and Chanvorachote P: Ecteinascidin 770, a tetrahydroisoquinoline alkaloid, sensitizes human lung cancer cells to anoikis. Anticancer Res 33: 505-512, 2013.

36 Sirimangkalakitti N, Chamni S, Suwanborirux K and Chanvorachote P: Renieramycin M sensitizes anoikis-resistant H460 lung cancer cells to anoikis. Anticancer Res 36: 1665-1671, 2016.

37 Wei L, Dai Q, Zhou Y, Zou M, Li Z, Lu N and Guo Q: Oroxylin A sensitizes non-small cell lung cancer cells to anoikis via glucose-deprivation-like mechanisms: c-Src and hexokinase II. Biochim Biophys Acta 1830: 3835-3845, 2013.

38 Park K-I, Park H-S, Kim M-K, Hong G-E, Nagappan A, Lee HJ, Yumnam S, Lee W-S, Won C-K, Shin S-C and Kim G-S: Flavonoids identified from Korean citrus aurantium L. inhibit non-small cell lung cancer growth in vivo and in vitro. J Funct Foods 7: 287-297, 2014.

39 Iwatsuki M, Mimori K, Yokobori T, Ishi H, Beppu T, Nakamori $\mathrm{S}$, Baba $\mathrm{H}$ and Mori M: Epithelial-mesenchymal transition in cancer development and its clinical significance. Cancer Sci 101: 293-299, 2010.

40 Yang J and Weinberg RA: Epithelial-mesenchymal transition: at the crossroads of development and tumor metastasis. Dev Cell 14: 818-829, 2008 .

41 Thiery JP, Acloque H, Huang RY and Nieto MA: Epithelialmesenchymal transitions in development and disease. Cell 139: 871-890, 2009.

42 De Craene B and Berx G: Regulatory networks defining EMT during cancer initiation and progression. Nat Rev Cancer 13: 97$110,2013$.
43 Onder TT, Gupta PB, Mani SA, Yang J, Lander ES and Weinberg RA: Loss of E-cadherin promotes metastasis via multiple downstream transcriptional pathways. Cancer Res 68 : 3645-3654, 2008.

44 Wong AS and Gumbiner BM: Adhesion-independent mechanism for suppression of tumor cell invasion by E-cadherin. J Cell Biol 161: 1191-1203, 2003.

45 Nieman MT, Prudoff RS, Johnson KR and Wheelock MJ: Ncadherin promotes motility in human breast cancer cells regardless of their E-cadherin expression. J Cell Biol 147: 631-644, 1999.

46 Wheelock MJ, Shintani Y, Maeda M, Fukumoto Y and Johnson KR: Cadherin switching. J Cell Sci 121: 727-735, 2008.

47 Mendez MG, Kojima S and Goldman RD: Vimentin induces changes in cell shape, motility, and adhesion during the epithelial to mesenchymal transition. Faseb J 24: 1838-1851, 2010.

48 Havel LS, Kline ER, Salgueiro AM and Marcus AI: Vimentin regulates lung cancer cell adhesion through a VAV2-Rac1 pathway to control focal adhesion kinase activity. Oncogene 34 : 1979-1990, 2015.

49 Hazan RB, Phillips GR, Qiao RF, Norton L and Aaronson SA: Exogenous expression of $\mathrm{N}$-cadherin in breast cancer cells induces cell migration, invasion, and metastasis. J Cell Biol 148: 779-790, 2000.

50 Thiery JP and Sleeman JP: Complex networks orchestrate epithelial-mesenchymal transitions. Nat Rev Mol Cell Biol 7: 131-142, 2006.

51 Al-Saad S, Al-Shibli K, Donnem T, Persson M, Bremnes RM and Busund LT: The prognostic impact of NF-kappaB p105, vimentin, E-cadherin and Par6 expression in epithelial and stromal compartment in non-small-cell lung cancer. Br J Cancer 99: 1476-1483, 2008.

52 Chunhacha P, Sriuranpong V and Chanvorachote P: Epithelialmesenchymal transition mediates anoikis resistance and enhances invasion in pleural effusion-derived human lung cancer cells. Oncol Lett 5: 1043-1047, 2013.

53 Huang RY, Wong MK, Tan TZ, Kuay KT, Ng AH, Chung VY, Chu YS, Matsumura N, Lai HC, Lee YF, Sim WJ, Chai C, Pietschmann E, Mori S, Low JJ, Choolani M and Thiery JP: An EMT spectrum defines an anoikis-resistant and spheroidogenic intermediate mesenchymal state that is sensitive to e-cadherin restoration by a src-kinase inhibitor, saracatinib (AZD0530). Cell Death Dis 4: e915, 2013.

54 Yadav A, Kumar B, Datta J, Teknos TN and Kumar P: IL-6 promotes head and neck tumor metastasis by inducing epithelialmesenchymal transition via the JAK-STAT3-SNAIL signaling pathway. Mol Cancer Res 9: 1658-1667, 2011.

55 Ko H: Geraniin inhibits TGF-beta1-induced epithelial-mesenchymal transition and suppresses A549 lung cancer migration, invasion and anoikis resistance. Bioorg Med Chem Lett 25: 3529-3534, 2015.

56 Yongsanguanchai N, Pongrakhananon V, Mutirangura A, Rojanasakul Y and Chanvorachote P: Nitric oxide induces cancer stem cell-like phenotypes in human lung cancer cells. Am J Physiol Cell Physiol 308: C89-100, 2015.

57 Chaotham C, Pongrakhananon V, Sritularak B and Chanvorachote P: A Bibenzyl from Dendrobium ellipsophyllum inhibits epithelial-to-mesenchymal transition and sensitizes lung cancer cells to anoikis. Anticancer Res 34: 1931-1938, 2014.

58 Unahabhokha T, Chanvorachote P and Pongrakhananon V: The attenuation of epithelial to mesenchymal transition and induction 
of anoikis by gigantol in human lung cancer $\mathrm{H} 460$ cells. Tumour Biol, 2016.

59 Chanvorachote P, Kowitdamrong A, Ruanghirun T, Sritularak B, Mungmee $\mathrm{C}$ and Likhitwitayawuid K: Anti-metastatic activities of bibenzyls from Dendrobium pulchellum. Nat Prod Commun 8: 115-118, 2013.

60 Busaranon K, Plaimee P, Sritularak B and Chanvorachote P: Moscatilin inhibits epithelial-to-mesenchymal transition and sensitizes anoikis in human lung cancer H460 cells. J Nat Med 70: 18-27, 2016.

61 Lin CC, Chen CC, Kuo YH, Kuo JT, Senthil Kumar KJ and Wang SY: 2,3,5-Trimethoxy-4-cresol, an anti-metastatic constituent from the solid-state cultured mycelium of Antrodia cinnamomea and its mechanism. J Nat Med 69: 513-521, 2015.

62 Farha AK, Dhanya SR, Mangalam SN and Remani P: Antimetastatic effect of deoxyelephantopin from Elephantopus scaber in A549 lung cancer cells in vitro. Nat Prod Res 29: 2341-2345, 2015.

$63 \mathrm{Wu}$ SH, Hsiao YT, Kuo CL, Yu FS, Hsu SC, Wu PP, Chen JC, Hsia TC, Liu HC, Hsu WH and Chung JG: Bufalin inhibits NCIH460 human lung cancer cell metastasis in vitro by inhibiting MAPKs, MMPs, and NF-kappaB pathways. Am J Chin Med 43: 1247-1264, 2015.

64 Huang SF, Horng CT, Hsieh YS, Hsieh YH, Chu SC and Chen PN: Epicatechin-3-gallate reverses TGF-beta1-induced epithelial-to-mesenchymal transition and inhibits cell invasion and protease activities in human lung cancer cells. Food Chem Toxicol 94: 1-10, 2016.

65 Gong WY, Wu JF, Liu BJ, Zhang HY, Cao YX, Sun J, Lv YB, Wu $\mathrm{X}$ and Dong JC: Flavonoid components in Scutellaria baicalensis inhibit nicotine-induced proliferation, metastasis and lung cancerassociated inflammation in vitro. Int J Oncol 44: 1561-1570, 2014

66 Bonnet D and Dick JE: Human acute myeloid leukemia is organized as a hierarchy that originates from a primitive hematopoietic cell. Nat Med 3: 730-737, 1997.

67 Ho MM, Ng AV, Lam S and Hung JY: Side population in human lung cancer cell lines and tumors is enriched with stem-like cancer cells. Cancer Res 67: 4827-4833, 2007.

68 Shi Y, Fu X, Hua Y, Han Y, Lu Y and Wang J: The side population in human lung cancer cell line NCI-H460 is enriched in stem-like cancer cells. PLoS One 7: e33358, 2012.

69 Zakaria N, Yusoff NM, Zakaria Z, Lim MN, Baharuddin PJ, Fakiruddin KS and Yahaya B: Human non-small cell lung cancer expresses putative cancer stem cell markers and exhibits the transcriptomic profile of multipotent cells. BMC Cancer 15: 84, 2015.

70 Liu J, Xiao Z, Wong SK, Tin VP, Ho KY, Wang J, Sham MH and Wong MP: Lung cancer tumorigenicity and drug resistance are maintained through $\mathrm{ALDH}(\mathrm{hi}) \mathrm{CD} 44(\mathrm{hi})$ tumor initiating cells. Oncotarget 4: 1698-1711, 2013.

71 Nolte SM, Venugopal C, McFarlane N, Morozova O, Hallett RM, O'Farrell E, Manoranjan B, Murty NK, Klurfan P, Kachur E, Provias JP, Farrokhyar F, Hassell JA, Marra M and Singh SK: A cancer stem cell model for studying brain metastases from primary lung cancer. J Natl Cancer Inst 105: 551-562, 2013.

72 Castano Z, Fillmore CM, Kim CF and McAllister SS: The bed and the bugs: interactions between the tumor microenvironment and cancer stem cells. Semin Cancer Biol 22: 462-470, 2012.

73 Murakami A, Takahashi F, Nurwidya F, Kobayashi I, Minakata K, Hashimoto M, Nara T, Kato M, Tajima K, Shimada N,
Iwakami S, Moriyama M, Moriyama H, Koizumi $\mathrm{F}$ and Takahashi K: Hypoxia increases gefitinib-resistant lung cancer stem cells through the activation of insulin-like growth factor 1 receptor. PLoS One 9: e86459, 2014.

74 Zhang Y, Zhang X, Huang J and Dong Q: Wnt signaling regulation of stem-like properties in human lung adenocarcinoma cell lines. Med Oncol 32: 157, 2015.

75 Jiang HL, Jiang LM and Han WD: Wnt/beta-catenin signaling pathway in lung cancer stem cells is a potential target for the development of novel anticancer drugs. J buon 20: 1094-1100, 2015.

76 Liu J, Mao Z, Huang J, Xie S, Liu T and Mao Z: Blocking the NOTCH pathway can inhibit the growth of CD133-positive A549 cells and sensitize to chemotherapy. Biochem Biophys Res Commun 444: 670-675, 2014.

77 Hassan KA, Wang L, Korkaya H, Chen G, Maillard I, Beer DG, Kalemkerian GP and Wicha MS: Notch pathway activity identifies cells with cancer stem cell-like properties and correlates with worse survival in lung adenocarcinoma. Clin Cancer Res 19: 1972-1980, 2013.

78 Zhang S, Wang Y, Mao JH, Hsieh D, Kim IJ, Hu LM, Xu Z, Long H, Jablons DM and You L: Inhibition of CK2alpha downregulates Hedgehog/Gli signaling leading to a reduction of a stem-like side population in human lung cancer cells. PLoS One 7: e38996, 2012.

79 Teng Y, Wang X, Wang Y and Ma D: Wnt/beta-catenin signaling regulates cancer stem cells in lung cancer A549 cells. Biochem Biophys Res Commun 392: 373-379, 2010.

80 Zhang X, Lou Y, Wang H, Zheng X, Dong Q, Sun J and Han B: Wnt signaling regulates the stemness of lung cancer stem cells and its inhibitors exert anticancer effect on lung cancer SPC-A1 cells. Med Oncol 32: 95, 2015.

81 Zhang X, Lou Y, Zheng X, Wang H, Sun J, Dong Q and Han B: Wnt blockers inhibit the proliferation of lung cancer stem cells. Drug Des Devel Ther 9: 2399-2407, 2015.

82 Liu YP, Yang CJ, Huang MS, Yeh CT, Wu AT, Lee YC, Lai TC, Lee CH, Hsiao YW, Lu J, Shen CN, Lu PJ and Hsiao M: Cisplatin selects for multidrug-resistant CD133+ cells in lung adenocarcinoma by activating Notch signaling. Cancer Res 73: 406-416, 2013.

83 Singh S, Trevino J, Bora-Singhal N, Coppola D, Haura E, Altiok S and Chellappan SP: EGFR/Src/Akt signaling modulates Sox2 expression and self-renewal of stem-like side-population cells in non-small cell lung cancer. Mol Cancer 11: 73, 2012.

84 Hou C, Sun B, Jiang Y, Zheng J, Yang N, Ji C, Liang Z, Shi J, Zhang R, Liu Y, Ye C and Zuo P: MicroRNA-31 inhibits lung adenocarcinoma stem-like cells via down-regulation of METPI3K-Akt signaling pathway. Anticancer Agents Med Chem 16: 501-518, 2016.

85 Bhummaphan $\mathrm{N}$ and Chanvorachote P: Gigantol suppresses cancer stem cell-like phenotypes in lung cancer cells. Evid Based Complement Alternat Med 2015: 836564, 2015.

Received August 15, 2016

Revised September 1, 2016 Accepted September 2, 2016 